\title{
Islamic Perspective on Syaifudin Ibrahim's Priester (Analysis Of The Views, Assumptions And Challenges Of The Reverend Syaifuddin Ibrahim Against Muslims)
}

\author{
Eko Nopriyansa \\ STAI Bumi Silampari Lubuklinggau Indonesia \\ ekonopriyansyah@gmail.com
}

\begin{abstract}
The phenomenon of religious people and freedom to choose religion as a belief in life becomes freedom that cannot be bargained. The series of past history reminds religious people that the Presence of Religion is on the most principle principle, in order to be a solution in various aspects of human life, apart from the dark history of Religion which is ridden by the interests of power and vice versa on the power of Religion. Furthermore, the context of the past is a compass of the future of Religion which is burdened by every follower of Religion. The presence of Christianity as a Missionary religion and Islam as a Da'wah religion opened a space for religious social dialogue, because both were involved in Agamanization. Furthermore, the two characteristics possessed by each religion will certainly ignite the enthusiasm of Christian evangelists and preachers on the part of Islam to compete in assuming the truth of the perspective. The presence of this article will open a space for scientific dialogue to the two communities, in exposing the views and assumptions of Reverend Murtadin Saifudin Ibrahim who has an Islamic background and assumes that he is one of the Islamic leaders who then turned to become a Christian priest. Furthermore this article is not an Interference to Saifudin Ibrahim's new beliefs, but this article is to answer Saifudin Ibrahim's assumptions and views on Islam as the largest religion among religious people in Indonesia. In the end, hopefully this article can answer various obscure views and thoughts, and thoughts that intercept the faith in Islam in Indonesia.
\end{abstract}

Keywords: Islamic, Perspective, Saifudin Ibrahim.

\begin{abstract}
Abstrak: Fenomena umat beragama dan kebebasan dalam memilih agama sebagai suatu keyakinan hidup, menjadi kebebasan yang tidak bisa di tawar-tawar. Rangkaian sejarah masa lampau mengingatkan umat beragama bahwah Kehadiran Agama pada pokok yang paling prinsip, guna menjadi sebuah solusi diberbagai aspek kehidupan manusia, terlepas dari sejarah kelam Agama yang ditunggangi kepentingan kekuasaan maupun sebaliknya kekuasaan yang ditunggangi Agama. Lebih jauh, konteks masa lampau merupakan kompas masa depan Agama yang di bebankan oleh setiap penganut Agama. Kehadiran Kristen sebagai agama Missioner dan Islam sebagai Agama dakwah membuka ruang dialog sosial keagamaan, karna keduanya terlibat dalam Agamanisasi. Lebih jauh dengan kedua karakteristik yang dimiliki masing-masing Agama tentunya akan membakar semangat para penginjil Kristen maupun para pendakwah dipihak Islam untuk berkompetisi dalam asumsi kebenaran Perspektif. Kehadiran tulisan ini akan membuka ruang dialog ilmiah kepada kedua komunitas, dalam menyingkapi pandangan dan asumsi Pendeta Murtadin Saifudin Ibrahim yang berlatar belakang Islam dan berasumsi sebagai salah seorang tokoh Islam yang kemudian berbalik arah menjadi Pendeta Kristen. Lebih jauh tulisan ini bukan merupakan Interpensi terhadap keyakinan baru Saifudin Ibrahim, namun tulisan ini guna menjawab asumsi dan pandangan Saifudin Ibrahim terhadap Islam sebagai Agama terbesar yang di anut umat beragama di Indonesia. Pada akhirnya semoga tulisan ini bisa menjawab berbagai pandangan dan pemikiran yang mengkaburkan, dan pemikiran yang menginterpensi Keimanan dalam berislam di Indonesia.
\end{abstract}

Kata Kunci : Islam Perspektif, Persfektif Islam, Saifudin Ibrahim. 


\section{Preliminary}

Religious freedom has become the slogan of all world religions, because religion should not only be a formality with the legitimacy of religious leaders or state legitimacy, but religion involves beliefs in substance and in substance. Furthermore, if we look at the context of religious freedom in Indonesia and compare with the freedom echoed by Malaysia, which states that the country's official identity is Islam or As, which states "its identity as a Christian nation." Indonesia's position is more mature in exposing the diversity of religions because of Indonesia does not claim the identity of Religion as the official State Identity, although on the other hand Indonesia also imposes certain restrictions on Religion. Furthermore, given this freedom of space, opened the axis for religious leaders to implement their beliefs freely without any worries about the clash of laws imposed in Indonesia.

Departing from the context of freedom that allows the Reverend Saifudin Ibrahim often expressed various views on Islam as a religion that he believed before turning toward Christianity. Furthermore, religion is a problem that is very urgent and very sensitive, we cannot say, because of that, every religious leader should present the impression of maturity in religion, ethics of dialogue and a spirit of tolerance should really be considered. Furthermore, the Islamic characteristics are inherent in its adherents as the substance of Islamic teachings, a former Roman Catholic priest from the Uniate Chaldean sect who converted to Islam in his work Muhammad In The Bible recalls the meaning of Islam in substance:

1 Abdu L'had Dawud, Muhammad In The Bible (Bina: Serawak, 1978), 109.
The Prophet jeremiah is the only prophet before Christ who useds the word shalom in the sense of a religion. He is the only prophet who uses this word whith the object of setting or proving the veracity of a messenger of god. According to the Qur'anic revelaton, Abraham, Ishmael, Isaac, Jacob, Moses and all the prophets were Muslims, and professed Islam as their religion..The term "Islam" and its equivalents, "Shalom" and Shlama," were known to the jews and Christians of Mecca and Medina when Muhammad appeared to perfect and universalize the religion of Islam. ${ }^{1}$

Furthermore, if we understand Islam as a Religion and if Pastor Saifudin must be honest, of course he can understand the substance of Islam and the characteristics of Islamic teachings as Rahmatallil Alamin. Perhaps this time it is important for all of us to be truly honest and objective in highlighting the phenomenon of Religion, especially in conducting studies and studies of Religions. Systematically, Professor Abuddin Nata in his methodology of Islamic studies clarifies and says that "there are a number of arguments that can be used to declare that Islam is a bearer of mercy for all nature." The inevitability of grace contextually, has been proven Islam in the course of history and its development. If we highlight the development of Islam in Southeast Asia "it grows and develops through trade routes without warfare." It is too naive if saifudin is so eager to undermine the Islamic faith by presenting his various personal experiences while becoming Muslim and too subjective to draw crucial conclusions in highlighting Islam, especially concerning the issue of faith. Saifudin further stated in his testimony, "The more I reflect on my old beliefs (Islam), the 
more it is revealed that the path I have taken is confusing and I don't want to be like Amrozi, Imam Samudra, or Nurdin M Top."

Harder saifudin in his video circulating on the youtube stated that there was no Prophet outside of Israel. The presence and emergence of the figure of Saifudin Ibrahim by interpreting the Qur'an in a haphazard manner becomes an important issue to be addressed by using a scientific approach, and a thorough study of the Existence of Islam objectively and in depth.

Departing from the background of the problem above, the writer is interested in studying, analyzing and answering comprehensively the various views and assumptions of the Reverend Saifudin Ibrahim who were thrown to Islam, both in understanding the history of Islam, its distrust of the prophethood of Muhammad SAW, to his interpretation of the verses of Al- the Qur'an in a haphazard manner, will be completed in the focus of this study. This assessment effort, of course, requires constructive criticism from all parties in order to improve this article in the future. In the end, hopefully this article can be useful and be a contribution to various parties.

\section{Research methods}

This writing based on literature study. The data in this study were obtained from written sources such as history books, articles, journals, and Audio Visual. Data collection is done by summarizing, organizing and formulating the opinions of experts contained in written documents such as books, journals, articles, Youtube, Ebook and others. Analysis of the data in this study, using the Gibb

\footnotetext{
2 Nata Abudin, Metodologi Studi Islam (Jakarta: Rajawali Pers,2006), 387.
}

research model that is "making the scriptures as a basis for thinking." 2

\section{Terrorism and Death by Islamic-Christian Perspective}

Saifudin's disillusionment with Islam to the point of deciding to become a Christian was partly due to the assumption that there were indications of internal Islam and certain spaces that allowed Muslims to commit murder at certain times and circumstances. Disappointment in Saifudin's perspective is a reason for him to become a Christian who is claimed to be unlike Islam. Therefore, this issue becomes important to understand and review in highlighting the phenomenon of terrorism.

Highlighting allegations blindly Saifudin, that about the murders allowed by Islam at certain times according to Shari'ah Law, not only in the Qur'an, long before the Qur'an, this law is also contained in the Bible and enforced as law. Furthermore, before answering Saifudin's assumption above, it is important to first look at the general scope for killing in certain circumstances from two ChristianChristian perspectives. Furthermore, in Islam that is quoted from the Muslim Sahih Bukhari, the history of Aisha said: "The Prophet cut the hand of someone who stole assets of more than one quarter of a dinar." ${ }^{3}$ We can also check the provisions and firmness of the law based on the scriptures in Numbers 15 Verse 27:

If even one person sins unintentionally, he must offer a year-old female goat as a sacrifice for sin. And the priest must make atonement before God for the person who did not deliberately commit that sin, so that the person

\footnotetext{
3 Al-Bayan, Shahih Bukhari Muslim, (Bandung: Jabal, 2013), 304.
} 
can obtain forgiveness because atonement was made for him. ${ }^{4}$

Furthermore, the Bible talks about the provisions or capital punishment which are more strict for idol worshipers, we can check the provisions of the death penalty in Deuteronomy 17 verses five to the seventh verse, "Then you must bring down men or women who have done evil deeds then go out the gate, then you must throw the man or woman with a stone to death ". If what Saifudin means is that Islam gives a signal of chaos only because it is contained in the Qur'an, the rules and conditions of jihad and war, again this assumption is irrelevant and unreasonable, because it is precisely the Bible in "Deuteronomy 20 verses 1 to verse 19 "Specifically the Bible discusses the law of war, but it is a superficiality if Muslims say that the Bible has a signal of murder, that is how Reverend Saifudin made efforts to corner Islam.

Moving further, in discussing terrorism, John L. Esposito in his work What Everyone Needs to Know About Islam translated by Norm Arbi'a Juli Setiawan said, "Islam does not defend and overwhelm Terrorism", Jhon's spirit series presents his work, in the context clarify the characteristics of Islam which do not justify acts of terrorism. Again, Saifudin's assumption in aiming at Islam is very unwarranted and Saifudin's claim to be a former Muslim with sikaf pretending not to know, that in Islam has an unconditional law that Muslims are "prohibited from committing sui cide", is a situation that is alarming, especially saifudin assesses Islam, only focused on the Islamic context without regard to the study of the text of the sources of Islamic teachings.

4 Lembaga Alkitab Indonesia, Alkitab (Jakarta: LAI, 2013), 189.
Departing from some of the explanations above, it is Saifudin's right to claim his views on Islam. However, the rights possessed cannot be used arbitrarily by accusing, justifying, without providing an accountable reference. It is true, religion can be used by any group to achieve the desires of power and ambitions of extremism, and all of this applies to all religions, but anyone should be able to occupy a different subject honestly, that the behavior of religious people, does not necessarily reflect the characteristics of religious teachings that he is anut. A shallowness, and a moral deterrence, if we punish the Characteristics of Religion based on religious behavior. Understanding religion correctly is by looking at the source of its teachings, not based on religious attitudes and phenomena that do not reflect the substance of religious teachings.

\section{Saifudin's Challenges Regarding PL and PB Harmony}

In the video uploaded on the youtube, Saifudin assumed, that in Islam has the historical root and conflicting errors contained in the Qur'an, unfortunately Saifudin did not show in detail where the verses that saifudin meant, which contained the contradictions, so the authors had difficulty identifying the contradictions the Qur'an referred to by Saifudin cannot be part of the focus of this study. Furthermore, this discussion will answer Saifudin's challenge regarding the claim that "the Qur'an is a book that is full of contradictions unlike the OT and NT Bibles, where no Muslim can prove that the OT and NT are contradictory. Before we study about Saifudin's claim that the books of the OT and NT books The series of holy books, both the

${ }^{5}$ Ibid, 136. 
Bible and the Qur'an, acknowledges that earlier the book of Taurah had arrived. In my writing published in the wardah journal UIN Raden Fatah before, entitled Analysis of the Biblical Text and the Qur'an in understanding the history of prophecy, the author has explained the position of the Taurah book both the Qur'anic perspective and the bible perspective. For further details:

The Torah is the rules and provisions contained in the book better known as the law of the Prophet Moses, namely the Book of Genesis, Exodus, Liviticus, Numeri, and the Book of Deoteronomium. (W.J.S. Poerdarminta, 2007: 1219). In addition, the word Torah in the Al-Kitab dictionary understood etymologically comes from the Hebrew Torah, meaning teaching from God which is set in the five books above. The understanding is in line with what is contained in the Al-Book dictionary, that the Torah is teaching by God, applied to the ten laws and regulations of God, especially in the five books of Moses or the Law. ${ }^{6}$

In that article, the author has explained the position of the Book of Taurah as a book that came long before the two MuslimChristian holy books, by positioning Taurah as a law that does not abolish the law of Taurah or the law of Moses. But instead the coming of the Bible is to fulfill the Book of Taurah far from the mission of removing the law of Moses. Jesus further stated emphatically:

Do not think that I have come to destroy the law or the prophets. I did not come to abolish it, but to fulfill it. Because I say to you before the disappearance of the heavens and the earth, a jot or a single point will not be removed from the law, Before all that

${ }^{6}$ See Journal Wardah Terbitan IAIN Raden Fatah Tahun 2019. happens, because of whoever negates even the smallest commandments of the law, and teaches it to others, He will occupy the lowest place in the kingdom of heaven but whoever does and teaches the commandments of the law, He will occupy the highest place in the kingdom of heaven. ${ }^{7}$

In line with the word contained in the Bible, it becomes something that has relevance to Saifudin Ibrahim's statement. Therefore, let us further examine the validity of Saifudin Ibrahim's statement. In this limited dialogue space, the author seeks to present two examples of conflict between the Old and New Testaments, due to space limitations and for the sake of simplification of the scope of the discussion, even though there are actually many conflicts between the OT and the NT such as regarding circumcision law, Alcohol law, context of Paul's letter so that religious practices, but the two examples below are considered sufficient as a general description of the OT and PB textually reviewed to answer Saifudin Ibrahim's challenge.

\section{About the Law of Eating Pigs}

Highlighting from the point of view of the Old Testament Book, precisely in Leviticus Eleven Seventh Verse "Likewise the wild boar, because it is firmly divided, that is, its hooves have long legs, but it does not ruminate, it is haram for you". Furthermore, the continuation of this verse is even more emphatic, "You must not eat the meat of the animals, and do not touch the carcass of these things for you. The priesthood in the book is part of the Epistle found in the Old Testament. More ironically, Saifudin seemed unwilling to know about Jesus' teachings in Matthew Article 5 Verses 17-21, so that Saifudin's view

\footnotetext{
${ }^{7}$ LAI, Lembaga Alkitab Indonesia,2013, 267.
} 
is exactly what the New Testament illustrates which clearly contradicts the Mosaic law confirmed by Jesus in Matthew 5 Verse 17 21 , if we move even further, to study the New Testament, exactly the OT and NT conflicts are numerous and used by Paul in some of the letters he wrote, again the NT has a conflict with the OT in the matter of the law of consuming pigs:

Then Jesus called out to the crowd and said to them, listen and remember, it is not what goes into the mouth that defiles a person, but what comes out of the mouth, that is what defiles a person ... Don't you know that everything that goes into the mouth goes down into the stomach and then dumped in the toilet. But what comes out of the mouth comes from the heart and that defiles people. ${ }^{8}$

In the opinion of Christians, regarding the consumption of pork and the law, is a Jewish tradition and is not a substance of God's teaching. Unfortunately, in the validity of Matthew 5 verses 17-21 it becomes a polemic in opposition to Jesus' statement in Matthew 15 , and automatically the law of eating pigs in the OT and NT Perspectives is contradictory in text, and opposition in context.

\section{Concerning the Conflicting Concepts of PL and PB Compliance.}

In Jewish thought a child of God means someone who has a physical relationship with God, and thus according to Prof. Al-a'zami, it is very possible that, "the early Christians used this title for Jesus in such a sense. Because they have been brought up in the Jewish Tradition. "If that is the case then the influence of Hellenism, where the Emperors like to see themselves as direct descendants of Gods or gods, can be regarded as responsible

${ }^{8}$ Lihat Matius 15 Alkitab Terbitan Lembaga Alkitab Indonesia,2013, 23. for changing His perception of people later Christians from the understanding of moral relations become a direct physical relationship. In the beginning was the Word, the Word was with God and the Word was God. He was with God in the beginning, All things were made by Him, and without Him nothing could have been made of all that was made. No one has ever seen God, but God's only child who is in the bosom of the Father, he said it ... You are my beloved Son, to whom I am pleased. The Son of Man is Lord of the Sabbath. ${ }^{9}$

From some thoughts and sharpening his views Al-A'zami, believes that Modern Text Analysis has thrown this reading into, "a confusion, with a version that currently has a replacement for him (Who Or Who) Manifestation perfectly." Furthermore, this debate about the question of the existence of the lordship of Jesus will continue to be a discussion among Christians, where many parts of the New Testament Verses (NT) do not have sufficient strong and accurate evidence, and even absolutely no evidence Authentic about the divinity of Jesus. Perhaps this is what strengthened DR. Zakir Naik, the Nobel laureate in the field of "King Faisal", loudly and courageously he challenged all Christians to prove from any version of the Bible where Jesus acknowledged himself by saying "I am God, Worship me ". Even more brave Naik said that if there is any Christian who can prove unambiguously, he is ready to convert to Christianity, and if he lies he is ready to put his head to be cut off.

Furthermore, in addressing this problem, we can highlight the many contradictions of the verses in the Bible itself that refute the divinity of Jesus, but the reality in Christian

\footnotetext{
${ }^{9}$ Lihat, Yohanes $1: 1-3$, Yohanes $1:$ 18, Lukas 3: 22, dan Lukas $6: 4$.
} 
religious practice even though they could not find concrete evidence of Jesus' own confession that he himself is God, Christians are still adamant to follow the faith taught taught down and down by the pioneers of the Christian religions of the past, such as the teaching of Paul. Further in highlighting the doctrine of the Trinity in the Bible, many verses refute the concept of the Trinity itself. The verse I mean is: ${ }^{10}$

The devil said to Jesus, all these things, they have all been given to me, which I will give to you, because they have been given to me and I have given them to whom I want. Then Jesus said, You must worship the Lord your God, and only you are filial. Jesus said also in other cities, I will preach the gospel of the kingdom of God. Because, for that I was sent. Look for crows, which do not sow and do not reap, and do not have warehouses or barns. However, being fed by God, then Jesus continues, how far you are above those birds. Jesus said, a servant cannot serve two elders. Because if so, he will hate someone and love others. You, can not serve both Allah and Mammon (Other than Allah). My teaching does not come from myself, but from the One who sent me. Whoever wants to do His will will know that My teaching is from God, or My teaching is from Myself. I can testify about them, really they are active for God, but without the right understanding. Because they do not know the truth of God and because they try to establish their own truth, they are not afraid of God's truth. Jesus said, the main law is, listen, O Israel, Lord our God, God is One. I am the Lord your God, who brought you out of the land of Egypt, from the place of slavery. Don't be there with You another God before You.

\footnotetext{
${ }^{10}$ Lihat : Lukas $4: 7-8$, Lukas $4: 43$, Lukas $16: 13$, Yohanes $7: 16-17$, Roma $1: 20-25$, Roma $9: 20$, Roma
}

Of the many verses of the Bible that I have explained, with logical reasoning, for people who have reason, can certainly use His thoughts and be a material for deep reflection about the various explicit meanings of the verses that I stated earlier, and actually, there are still so many verses that are similar but I think some of the verses that I have explained above can be said to be sufficient to state how the general description is textually. About how the Bible itself tells about the divinity of Jesus in the Bible. If we agree with a few examples of verses above, we actually already have a common view of Jesus' Divine Existence. But if we cross, then this shows that so many verses in the Bible experience confusion and contradiction between one verse and another.

Moving further, if we go back to the Bible Luke 4: 6-8, where when Satan tempted Jesus in the wilderness, the Bible version, Satan offered Jesus Palace and worldly pleasures, but Jesus himself snapped at Satan and shouted, " You only serve God. "The secret is, why did Jesus say to Satan" It is only God that you serve. That should be if Jesus is God as most Christians believe, a valid word should be used in bearing this witness, let Jesus say, only you worship or to us all three of you worship. But His context is not like that, and Jesus has told the truth. It means that Jesus also surrendered to Allah (Muslim).

In this case we do not intend to justify our Christian brothers and sisters. However, I want to open our understanding to be sharper and have a critical attitude. Because, the problem of faith in the divinity that we believe in, is a problem that is the most basic and substantial in religion. It is not only reckless to follow the religion of our parents without

$10: 2-3$, Markus $12: 29$, Keluaran $20: 2-3$, Imamat 10 : 2 , Imamat $18: 4-5$. 
further understanding the basis of the faith that we follow. Furthermore, in Luke 4: 43, Jesus said that he had a mission to preach the Gospel (For the Children of Israel) in several cities, where Jesus also stated that for the mission he was sent by God, meaning that Jesus did not deny that he was the Messenger of God. And what often makes us miss in Luke 16: 13, a very remarkable parable in both its content and meaning, Jesus describes how the Kahika and the human character cannot impose the observance of Dualism, such as serving two masters. If Jesus doubts our spirit in serving two masters, again if we serve two Gods. Perhaps this can be an ingredient for our reflection that Jesus did not justify the concept of the trinity.

The simplest conclusion is that Saifudin Ibrahim's lack of knowledge in understanding the Scriptures that he was Imani, revealed a shallow superficiality. How is it possible, one side of Jesus said his coming was not to abolish even a single point of Moses, but many parts of the Moses law itself were rejected and contradicted by the New Testament, then Saifudin confidently said the Bible had no conflict between the OT and the NT like Al- the Qur'an. But none of it can provide a reference and location of the contradictions of the Qur'an.

\section{Spiritual Peace in Islamic Concepts}

One of the strong reasons that Saifudin claimed was why he left Islam as his initial belief, because he did not find peace in the religion he professed before (Islam). Various phenomena seen by Saifudin especially in the Indonesian context Saifudin It seems that it is only focused on cases of social violence by some Muslim communities, terrorism, radicalism and the like, for that Saifudin chose Christian as his new religion, this discussion is not at all intended to intervene in Saifudin's new beliefs, but this paper in order to answer the recognition that is too subjective to conclude Islam based on personal experience. The defect of Saifudin's thought in concluding Islam, is evident from the arrogance of the logic used. Saifudin was only present by showing Negative law, without seeing the slightest phenomenon of religious relations in the context of Indonesia as a whole.

Further, Saifudin's disability accusations against Islam can be seen in his manner without presenting analyzes that can be scientifically justified. The violence committed by various Indonesian Islamic communities referred to saifudin, was not based on the real data, it was seen from his call to see the Google Website and the news as a reference. Furthermore, it may be important to note that the strength of the media stream is sometimes not a fact that is in the field one example of "the opinion of Islamization in East Timor in the 1990s that has always been raised by Bishop Belo to the outside media, despite the fact that the growth rate of Religion in Prof. research Bilver Singh from Singapore proved that the Tim Team case was not Islamization but Catholicism."11

Understanding and studying the phenomenon of Missionaries and da'wah in the Indonesian context with various moderation of thought and approach, it is time to understand a religion by tracing the Main Sources of Religion, not based on the Context of religious adherents. Furthermore, by referring to authentic and scientifically

11 Husaini Adian, Kerukunan Beragama dan Kontroversial Penggunaan Kata Allah dalam Agama Kristen (Jakarta: Gema Insani, 2015), 19. 
accountable sources, not only can it be an added value to enrich identity as a place to study literature in meeting Academic and personal needs and demands, but it can also become a driving force and can motivates us to stimulate ways of thinking in order to give birth to various paradigms and contributions of thought that are beneficial to religious, national and state life, especially in the religious field. Referring to some of the reviews in the last note that were shown earlier, the suggestions that I consider important are simply:

To young activists as well as researchers in the social and religious fields, I hope this article can be made as an evaluation and comparison material to examine further and in-depth on various wild thoughts and issues that attempt to undermine Islam with various models and are wrapped with frames all Academic, Modern and contemporary, which certainly has a considerable impact on the knowledge and understanding of Islam.

To the reader in general, of course, I hope that this article will become an added value, in adding to the Khazanah of Knowledge and religious insight. which in the end can be a work that is useful for academics in particular, and the wider community in general.

\section{Conclusion}

In establishing relations between Muslims and Christians in the Indonesian Context, the two communities, both Islamic and Christian figures, must realize that basically each religious follower must have the same passion and desire to establish harmonious and friendly relations between religious communities. . It is the duty of both communities to engage in religious dialogue and take Universal values from both communities for the sake of life under the auspices of and the common ideals of the Indonesian people And what is not important, whoever he is and from any religion background, when he has an attitude of curiosity and wants to establish dialogue, must pay close attention to religious sources that are a comparison in conducting studies and used as material that will be presented to the public. Because throwing accusations without referring to the main references of each religion, is a shallowness in the name of God and Perspective truth. Hopefully, from some of the explanations in the discussion presented in this paper, it can be a contribution and added value in studying the Islamic Khazanah, especially for those who are interested in comparative Religion, Study of Religions, and Islamic thought.

\section{References}

Abdu L'had Dawud, 1978. Muhammad In The Bible (Bina: Sarawak)

Adian Husaini, 2013. Philosophy of western and Islamic perspective of science. (Jakarta: Gema Insani).

Indonesian Bible Institute, 2013 (Jakarta: LAI)

Al-A'zami, MM, 2005. The History Of The Qur'anic Text. (Jakarta: Gema Insani).

Arifin An-Nakrawie, without the year of publication. Asbabul Wurud. (Surabaya: Efforts).

Adian Husaini, 2005. The face of western civilization from the Christian hegemony of secular-liberal Christianity. (Jakarta: Gema Insani).

Abudin Nata, 2006. Islamic study methodology. (Jakarta: Rajawali Press). 
Alwi shihab, 1999. Inclusive Islam. (Bandung: Mizan Publishers Collaborate with ANTEVE).

Ahmad al-Usairy, 2011. History of Islam since the Prophet Adam until the XX century. (Jakarta: Akbar Media).

Bustanuddin Agus, 2005. Religion in human life. (Jakarta: PT. Raja grafindo persada).

Bediuzzaman said Nursi, 2011. The mystery of life and resurrection after death. (Jakarta: Erlangga Publisher).

Bahtiar Effendy, 2000. Islamic Politicians. (Bandung: Mizan).

Balai Religious Development, 2013. Message of peace from the pulpit Friday. (Jakarta: Balai LITBANG Agama Jakarta).

Cangara Hafied, 2011. Introduction to Communication Studies. (Jakarta: PT. Raja grafindo persada).

Ministry of Religion of the Republic of Indonesia, 2006. Al-Qur'an and His Translation. (Jakarta: Cv. Agung Harapan).

Ministry of Religion of the Republic of Indonesia, 1994. Al-Qur'an and His Translation. (Jakarta: Translation Agency and Pentashih).

The Indonesian Ministry of Religion, 2004. Halal product guarantee standards according to the MABIMS State. (Jakarta: Directorate General of Community Guidance and Hajj Halal Product Development Project).

Muhammad Idrus, 2009. Social Science Research Methods. (Jakarta: Erlangga Publisher).

Muhammad Imarah, 1999. Islam and Plurality. (Jakarta: Rajawali Press).
Murodi, 1997. History of Islamic culture. (Semarang: PT. Karya Toha Semarang). Muhammad S'id Ramadhan Al-Buthi, 1999. Scientific Analysis of the history of the Islamic Movement in the time of the Prophet Muhammad. (Jakarta: Robbani Press).

Margono. S, 2007. Educational research methodology. (Jakarta: Rineka Cipta).

Munawir Warson, 1994. Munawwir Dictionary, (Jakarta: Progressive Literature).

Munawir. A. W, 2017. Indonesian-Arabic Dictionary. (Surabaya: Progressive Library).

Mundiri, 2012. Logic. (Jakarta: PT. Raja grafindo Persada).

Robert. D. Lee, 2000. Overcoming Tradition and Modernity: The Search for Islamic Authenticity. (Translated by: Ahmad Baiquni). (Bandung: Mizan).

Rohimin. Et al. 2009. Harmonization of Religion and Culture in Indonesia. (Jakarta: Jakarta Research and Development Center for Religion).

Shihab, Quraish, 1999. Qur'anic Insights. (Bandung: Mizan).

Syukir, Asmuni, 1983. Islamic Da'wah Strategies. (Surabaya: National Business).

W. J. S. Poerdarminta, 2007. General Indonesian Dictionary. (Jakarta: Balai Pustaka).

Yatim, Badri, 2000. History of Islamic Civilization. (Jakarta: Rajawali Press). 